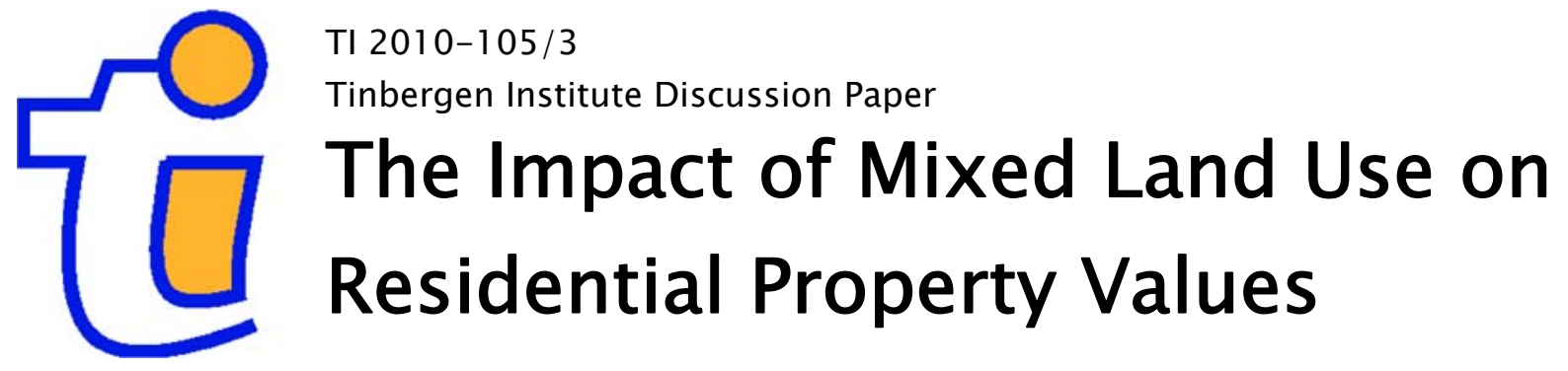

Hans R.A. Koster

Jan Rouwendal

VU University Amsterdam, and Tinbergen Institute. 


\section{Tinbergen Institute}

The Tinbergen Institute is the institute for economic research of the Erasmus Universiteit Rotterdam, Universiteit van Amsterdam, and Vrije Universiteit Amsterdam.

Tinbergen Institute Amsterdam

Roetersstraat 31

1018 WB Amsterdam

The Netherlands

Tel.: +31(0)205513500

Fax: $+31(0) 205513555$

Tinbergen Institute Rotterdam

Burg. Oudlaan 50

3062 PA Rotterdam

The Netherlands

Tel.: + $31(0) 104088900$

Fax: $+31(0) 104089031$

Most TI discussion papers can be downloaded at http://www.tinbergen.nl. 


\title{
The Impact of Mixed Land Use on Residential Property Values
}

\author{
Hans R.A. KOSTER, VU University Amsterdam* \\ Jan ROUWENDAL, VU University Amsterdam
}

This version: October 15, 2010

\section{Summary}

Contemporary European urban planning policies aim to mix land uses in compact neighbourhoods. It is presumed that mixing land uses yields socio-economic benefits and therefore has a positive effect on housing values. In this paper, we investigate the impact of mixed land use on housing values using semiparametric estimation techniques. We demonstrate that a diverse neighbourhood is positively valued by households. There are various land use types which positively affect house prices, e.g. business services and leisure. Land uses that are incompatible with residential land use are, among others, manufacturing and wholesale. It appears that households are willing to pay up to 6 percent more for a house in a mixed neighbourhood than for an otherwise comparable house in a monofunctional area. We also show that there is substantial heterogeneity in willingness to pay for mixed land use. For example, apartment occupiers are willing to pay almost 25 percent more for diversity than households living in detached housing.

Keywords: Mixed land use; diversity; hedonic price analysis; semiparametric estimation;

\section{Acknowledgements}

We would like to thank the NVM and Statistics Netherlands for providing data. The paper has benefited from a NICIS-KEI research grant. We are indebted to Piet Rietveld, Wouter Jacobs and Wendy Tan for valuable comments.

\footnotetext{
* Corresponding Author. Department of Spatial Economics, VU University, De Boelelaan 11051081 HV Amsterdam, e-mail: hkoster@feweb.vu.nl.
} 


\section{Introduction}

Mixed land use has become one of the backbones of contemporary planning policies such as Smart Growth and New Urbanism. In Europe as well, the widely implemented Compact City Concept aim to increase densities and mixed land use (Koomen et al., 2008; Rowley, 1996). Many European cities pursue relatively stringent land use policies. It is therefore surprising that debates on compact development and mixed land-use are much less heated in Europe than in the United States (Dieleman et al., 1999; Van der Valk, 2002).

Despite a wide variety of definitions, the European compact city concept generally focuses on relatively high-density, mixed neighbourhoods in terms of land use, that are well accessible by public transport (Burton, 2000). Underlying the popularity of this concept is the belief that the co-location of social functions leads to a sustainable and liveable urban environment. However, there are some critical voices that argue that this concept is mainly supply-driven, while individual's preferences do not play a role in decisions of (local) governments. It is also argued that the benefits and costs of mixed use, as well as compact development have not been well understood (Jenks et al., 1996; Dieleman et al., 1999; Burton, 2000)

In this paper, we contribute to the literature by investigating preferences of home-owners for mixed land use. Mixed land use is considered as an important component of the compact city concept, as compactness implies proximity of households to each other, but also to different types of land use (see Rowley; 1996). More specifically, we attempt to determine the effect of mixing employment and residential land use on housing values, by means of a semiparametric hedonic house price analysis. Hedonic price techniques are useful in investigating to what extent consumers appreciate neighbourhoods with mixed land use. A common idea in the compact city concept is that in attractive urban areas, each neighbourhood provides a sufficiently rich variety of functions, which allows its inhabitants to realize all their daily activities without having to move to other parts of the city (Handy, 1992; Breheny, 1994). Grocery shops, basic amenities, and sufficient employment for the inhabitants of the neighbourhood should preferably be available within walking distance. Clearly, this 
is only possible if there is a variety of jobs in each neighbourhood, and this is the main reason why we focus on employment. We distinguish between employment in various sectors, since it may well be the case that - for instance - the presence of restaurants and shops has effects that are different from those of a manufacturing plant in a neighbourhood. Mixing employment and residential use is arguably one of the most important aspects of mixed land use, but certainly does not cover it completely. Other potentially relevant aspects - like mixing various types of housing in residential areas - are ignored in the present study. The basic hypothesis to be tested is then: do home-owners value mixing of employment and households?

This study adds to the literature in three important aspects. First, most studies make strong assumptions on the functional form of the hedonic price function. Ekeland et al. (2004), among others, argue that the relationship between house prices and various attributes is complex and nonlinear, which implies that it is hard to defend any specific functional form on a priori grounds. It is therefore preferable to avoid such assumptions through the use of non-parametric or semiparametric specifications.

Second, in the literature it is often assumed that some uses are compatible with residential land (e.g. business land), whereas others are not (e.g. industrial land). This seems plausible, but empirical work that confirms (or rejects) this suggestion appears to be scarce. Using a rather detailed classification of sectors, we are able to provide more insight in which uses are compatible with housing and which are not.

Third, our estimation procedure leads to distributions of preferences for different aspects of mixed land-use. We relate these distributions to different submarkets and price segments of the housing market to learn about households' preferences for mixed land use. The current literature concerning the impact of mixed land-use on house prices only pays attention to the impact on single-family homes, but we may investigate whether the impact of mixed land use on the prices differs over various types of housing (Aurand, 2010). 
The paper proceeds as follows. Section 2 introduces the Compact City Concept and discusses previous hedonic studies that investigate the effects of mixed land use. In Section 3 the data is described and the regional context is considered. Section 4 discusses our estimation techniques. In Section 5 we present our results, which is followed by a sensitivity analysis in Section 6 . Section 7 concludes.

\section{Literature review}

\subsection{The Compact City Concept}

Mixed land use is defined as a mixture of commercial, residential and industrial land within a certain area (Aurand, 2010). In the ancient Greek and Roman cities, but also in the cities of the Middle Ages, living, working and shopping were all located within the city walls (Wright, 1967; Coupland, 1997). In the early $20^{\text {th }}$ century this 'natural' co-location of land uses came to an end. Owing to technological progress, especially in the transport sector, and changes in cultural behaviour, land uses were often separated (Grant, 2004). Nevertheless, cities in Europe have evolved differently than American cities (Anas et al., 1998). There is a great mixture of business and services in the services, mainly because of the presence of cultural amenities. Furthermore, public transportation plays a more important role in daily travel. Urban growth patterns are also more regular because of more stringent imposition of land-use controls and other types of urban planning (Batty and Longley, 1994; Anas et al., 1998).

In 1961 Jacobs (1961) was the first to argue that a balanced mix of living and working in an urban block may lead to liveable, safe and viable neighbourhoods. More than a decade later the compact city policy was introduced in Europe and enjoyed its heyday in the 1980s (Faludi and Van der Valk, 1994; Korthals Altes, 2007). In 1990 the European Commission still promoted the compact city, mixed land use and social and cultural diversity within neighbourhoods (Breheny, 1995; Rowley, 1996). More recently, more emphasis is put on the relationship between mixed use and compact development (Vreeker et al., 2004). In a report of the European Commission, it is advised to focus on mixed development, in order to protect open space, reduce energy consumption, improve access to services 
and facilities, utilise infrastructure more efficiently and generate agglomeration economies (Burton, 2000; Working Group on Sustainable Land Use, 2001; Vreeker et al., 2004). However, it is argued that the costs of land use policies have not been weighed to potential gains (Gomez-Ibanez, 1991). Costs that may arise because of mixed compact development may be congestion effects, a rise in property costs and conflicts between different land uses (think of visual, noise and air pollution) (Breheny, 1992).

In Europe there are very few studies that systematically test impacts of land use policies, as well as investigate preferences of individuals and firms for specific lay outs of the spatial environment. In this paper we aim to gain insight in the preferences of home-owners for mixing of employment and residential land use, employing a hedonic price approach.

\subsection{Hedonic studies}

Hedonic price studies have been popular in economics ever since Griliches (1961) study of the automobile market and especially since Rosen's (1974) analysis that emphasised the relationship between the partial derivatives of the hedonic and the marginal willingness to pay for attributes of differentiated goods. Urban economics is a major field of application of this methodology (Sheppard, 1999). This technique is useful to investigate to what extent consumers appreciate neighbourhoods with mixed land use but less suitable to analyse issues like sustainability and viability which are not

necessarily (completely) reflected in the preferences of the current occupiers but may be desirable for other reasons.

A well known concern with the hedonic price methodology is the impact of the choice of a particular functional form for the hedonic price function on the results. For instance, the popular loglinear specification implies that marginal willingness to pay for any attribute varies inversely with the price of the house, which may or may not be a property of the data at hand. The more flexible BoxCox transformation which was developed to address this problem is still restrictive in that it uses a particular functional form to globally describe the data. More recently, nonparametric techniques 
have been developed to avoid this limitation. A problem with the latter technique is that it is very data-intensive, as most hedonic price functions contain a large number of explanatory variables.

Since this practice addresses the risk for omitted variable bias, another well known concern in the hedonic methodology, in many cases one cannot solve the problem by a parsimonious specification of the hedonic price function. However, there are some recent studies that propose a partially nonparametric estimation of the hedonic price function. These hold the promise for the researcher to have the best of both worlds: a nonparametric estimate of the effects of primary interest and avoidance of the curse of dimensionality associated with a fully nonparametric approach. Since our focus is on mixed land use, we will adopt a specification in which the part of the hedonic that refers to this aspect is left unspecified, while we use the familiar linear specification for the other parts of the hedonic.

A few papers have used the hedonic method to investigate the effects of mixed land use. In two early studies, Cao and Cory (1981) and Lafferty and Frech (1978) find that residential property values increase when the amount of industrial and public land increases. Cao and Cory also discover that commercial land and non-single family homes have a positive impact on residential properties. They conclude that an optimal mix of land uses must be sought, whereas monofunctional land-use or separation of the different activities must be discouraged. Burnell (1985) concentrated on the effects of industrial land use on residential property values in Cook County, Illinois. He made a distinction between localized and non-localized externalities and found that residents value the presence of industrial activity positively, although property values are lower in municipalities that suffer from severe pollution. ${ }^{1}$ An increase in commercial use will also lead to an increase in the property values. Burnell concluded that not only the presence of industrial activity is important but also the type of industrial activity.

More recently, Song and Knaap (2004) have analysed the effects of mixed land uses on house prices in a fully parametric setup. Their main finding is that mixing commercial activities with

\footnotetext{
${ }^{1}$ An example of a localised externality can be visual pollution, while an example of a non-localized externality is air pollution.
} 
residential use will affect house values positively. The ratio of service jobs-to-residents has a small positive effect. The authors conclude that it is very important how the land is mixed: there must be a careful selection of the activities that are to be mixed. This observation is in line with their earlier study of policies related to New Urbanism (Song and Knaap, 2003) in which they develop quantitative measures of urban form and perform a hedonic price analysis. Their findings suggest that some of the design features of New Urbanism (amongst others, mixed use and accessible commercial land use) are capitalized in higher residential property values, while other features do not have a significant impact. To further address these issues, we will disaggregate employment to industrial sectors.

We may conclude that there is some evidence that the presence of particular types of industrial land use in residential areas can lead to higher property values. However, most of the research uses rough classifications of employment (industrial, commercial or residential land) and merely investigate the effect on single-family houses.

\subsection{How to measure mixed land use?}

We noted above that the available literature pays scant attention to the impact of mixing employment with residential land use. It is assumed that households will like (and prefer) a mixed urban environment in terms of different land uses other than housing. In our setup, where employment is an indicator for land use, this suggests that not just the number of jobs, but also the composition of total employment in terms of industries matters for mixed land use. We therefore define a diversity index so as to be able to examine the impact of a mixture of employment and housing on property values. Let $H_{h}$ denote the number of households in a neighbourhood of house $h$ and $E_{g h}$ the number of employees in sector $g$. The diversity index $D$ for house $h$ is the inverse of the HirschmannHerfindahl index: ${ }^{2}$

$D_{h}=1 /\left(\sum_{\forall g}\left(P_{g h}^{2}\right)+P_{H h}^{2}\right)$,

\footnotetext{
${ }^{2}$ In the sensitivity analysis, we will provide also the effects of other indices on housing values.
} 
where $P_{g h}=E_{g h} /\left(H_{h}+\sum_{\forall g}\left(E_{g h}\right)\right)$ and $P_{H h}=H_{h} /\left(H_{h}+\sum_{\forall g}\left(E_{g h}\right)\right)$. In other words, $P_{g h}$ and $P_{H h}$ represent respectively employment and household shares of the sum of employment and households. If activities in the neighbourhood of the house under consideration are fully concentrated in one sector, or when only households occupy in the neighbourhood of house $h$, we find $D_{h}=1$ and this index increases as activities in this neighbourhood become more diverse (see Duranton and Puga, 2000). We will include $D_{h}$ in our hedonic equations to examine whether households value the mix of employment.

When mixed land use is implemented, not only the neighbourhood as a whole will change, measured by our index, but also specific land uses will affect house prices. We will also pay close attention to the effect of different types of employment on residential property values.

\section{Data sets and regional context}

\subsection{Data sets}

Our analysis is based upon three data sets. The first data set is from the NVM (Dutch Association of Brokers) and consists of 10,152 housing transactions. It contains information on about 80 percent of all transactions in 2006 in the Rotterdam City Region. The data set includes a number of structural attributes of the house, such as size, number of rooms, and type of house. We removed a small number of observations. ${ }^{3}$

The second database was constructed by the Chamber of Commerce, which comprises data from all firms/establishments that were located in the Rotterdam City Region in 2006. From these 43,911 firms we have information about the location on a 6-digit postcode (PC6) area, the number of employees, and the establishment's sector including the agricultural sector, business services, education and healthcare, government, manufacturing, leisure (cafés, cinemas etc.), retail and

\footnotetext{
3 We deleted all transaction prices below $€ 25,000$ and above $€ 2.5$ million. We also removed all observations which refer to properties smaller than $25 \mathrm{~m}^{2}$ or $100 \mathrm{~m}^{3}$ and larger than $500 \mathrm{~m}^{2}$ or $2000 \mathrm{~m}^{3}$. After these deletions, the database consists of 10,057 values.
} 
wholesale. ${ }^{4}$ Because it is somewhat unclear what agricultural employment measures (does is for example measure the accessibility to open space?) we exclude it from the analysis. In the literature, mixed land use is sometimes defined as mixing compatible uses, and therefore industrial land use is excluded (Calthorpe and Fulton, 2001). However, we want to find out which uses are compatible with residential use and do not want to exclude industrial use from the outset.

We also use a database at PC6-level, obtained from Statistics Netherlands, that provides us information about the number of households living in this postcode in 2005 , as well as the share of ethnic minorities in the postcode. Furthermore, we gather information on the distance to the nearest 1000 square meter of open space. For each property we also compute the distance to the city centre of Rotterdam, the nearest highway ramp and the distance to the nearest railway station.

These datasets were integrated into a single database that contains for each house the transaction price, a number of structural attributes, a number of neighbourhood variables, such as accessibility measures, share of ethnic minorities and distance to open space, and a number of variables that indicate the amount of mixed land use by means of our proposed index and the presence of employees in each sector.

To construct variables that measure mixed land use, we rely on geographical information systems and determine for each property a buffer. We sum employment in different sectors in propertyspecific buffers. So, employment measures as well as indices of mixed use are property-specific. We think that the use of a buffer is more convenient than a predefined neighbourhood because the size of each buffer for each house is the same and is not subject to arbitrarily-defined neighbourhood boundaries. We assume a buffer radius of 500 meter because we may expect that the effects of mixed land use are very local. ${ }^{5}$ Table A1 in Appendix A presents the descriptive statistics of the selected variables.

\footnotetext{
${ }^{4}$ A 6-digit postcode area is a small and comparable to the size of a census block in the United States. It is an area inhabited by on average 17 households.

${ }^{5} \mathrm{~A}$ number of studies indicate that the effects of the environment on the value of a house have a localised nature. For example, Palmquist (1992) and Kiel and Zabel (2001) find that a number of environmental effects have a localized impact on residential property values. Also Rouwendal and Van der Straaten (2008) found that
} 


\subsection{Regional context}

This Rotterdam City Region is located in the west of the Netherlands and hosts the largest port in terms of traffic in Europe. Figure 1 shows a map of the City Region, which consists of 16 municipalities. We compute the average diversity index for a postcode area. Especially in the city centre of Rotterdam and Schiedam the diversity of uses is high. There are also a number of areas that are largely monofunctional. For example, some port areas (e.g. Europoort), as well as residential areas in the east of the Rotterdam City Region. The maps on the right display the employment and household density in the City Region. Employment is predominantly concentrated in the centre of Rotterdam, Schiedam and Vlaardingen, whereas residential use is more spread over the region.

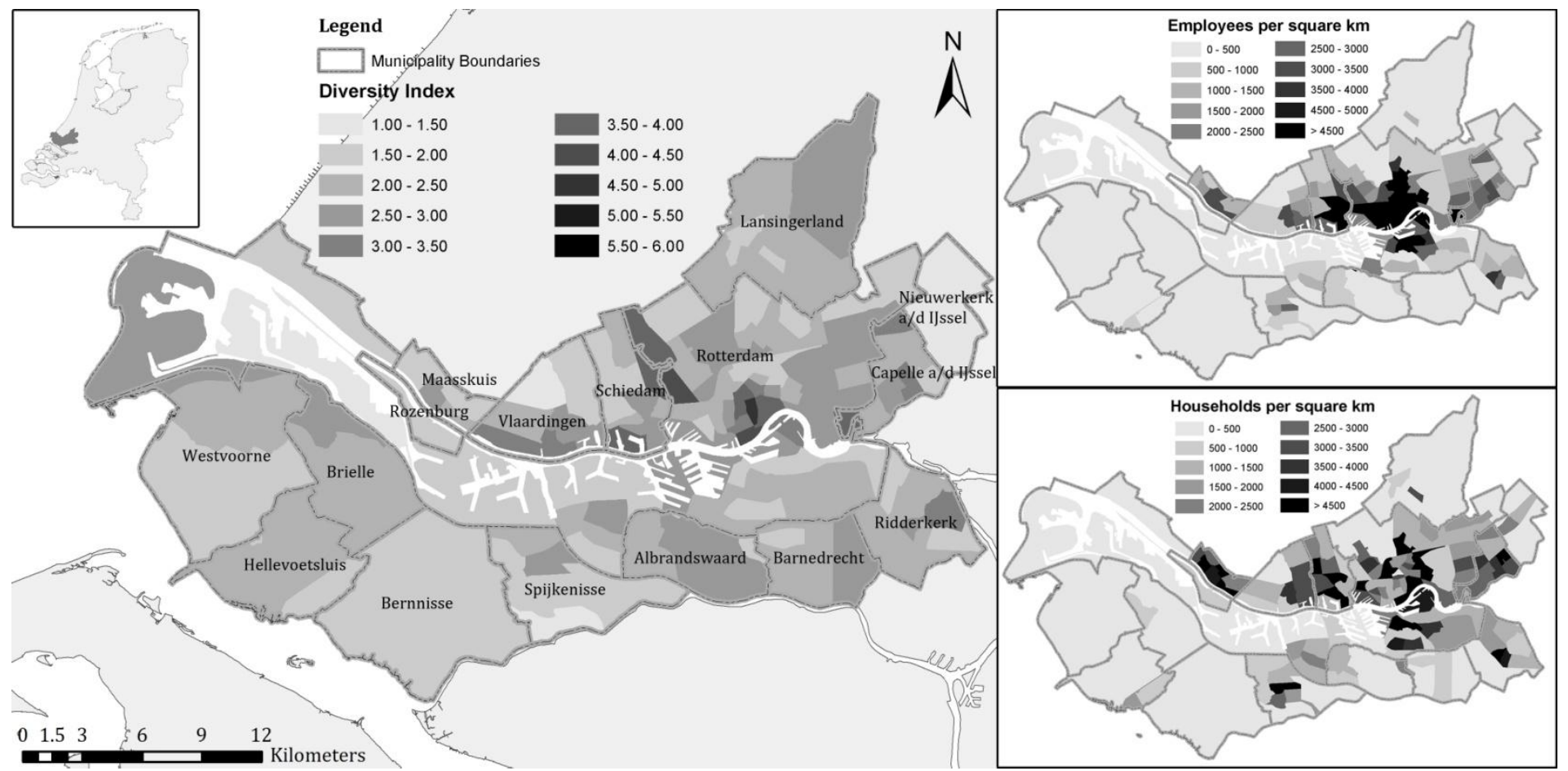

Figure 1: The Rotterdam City Region

the effects of open space are localized (within 500m of each house). A buffer size of 500 meter is therefore a natural starting point of the analysis. 
The total population of the Region was 1,175,630 in 2006, which is about 7 percent of the national population. Rotterdam is by far the largest city in the Region with 584,060 inhabitants and is the second largest city in the Netherlands. However, the city is struggling with a relatively high share of unemployment, low average income and low educational levels compared to other cities in the Netherlands (Statistics Netherlands, 2007). One aim of local policies is therefore to attract high skilled workers and high income households by offering, among other things, an attractive and dynamic urban environment (Municipality of Rotterdam, 2010). The Municipality of Rotterdam is developing special areas where residential and commercial activities are co-located. An example is the redevelopment of a number of former port areas into vibrant mixed use areas. The white paper 'Stadsvisie Rotterdam 2030' (Municipality of Rotterdam, 2007) cites the Lloyd quarter and the Wilhelminapier as examples of such mixing of in one area:

"A particular area in Delfshaven is the Lloyd quarter, a former port area, where there is a mix of living and working."

And:

"The Wilhelminapier [is] a location with a rich history, a skyline and an attractive mix of living, working, culture, hotels, restaurants and other urban amenities [...]. This will be the trendy, most vibrant mixed urban area of Rotterdam."

Because there are numerous examples of actual mixed land-use as well as more monofunctional areas, the city region of Rotterdam is a suitable region to study the effects of mixed land-use. Actually, we can compare the impact of having a mixed urban environment with the effects of a more monofunctional lay out. 


\section{Model estimation}

\subsection{Fully parametric hedonic price functions}

A linear or loglinear specification of the hedonic price function is often used because it is easy to interpret the coefficients (Freeman, 1993): in a linear specification the coefficients are equal to the (constant) marginal prices, while in a loglinear specification the coefficients denote (constant) elasticities. Following this empirical practice, we will start with these specifications of the hedonic price function. The linear function is:

$P_{h}=\alpha_{0}+\alpha_{1} D_{h}+\alpha_{2} H_{h}+\sum_{\forall g} \alpha_{g} E_{g h}+\sum_{\forall k} \beta_{k} X_{k h}+\sum_{\forall d} \beta_{d} X_{d h}+\sum_{\forall m} \beta_{m} \theta_{m h}+\epsilon_{h}$

where the $\alpha$ 's and $\beta$ 's are the coefficients to be estimated, $X_{k}$ are continuous control variables, $X_{d}$ are dichotomous control variables or shares, $\theta_{m}$ are municipality fixed effects to control for unobserved spatial heterogeneity and $\epsilon_{h}$ is the house-specific error term. This imposes constant marginal prices for all characteristics included, which may be unrealistic. The double-log specification may therefore be preferred:

$\log P_{h}=\alpha_{0}+\alpha_{1} D_{h}+\alpha_{2} H_{h}+\sum_{\forall g} \alpha_{g} E_{g h}+\sum_{\forall k} \beta_{k} \log X_{k h}+\sum_{\forall d} \beta_{d} X_{d h}+\sum_{\forall m} \beta_{m} \theta_{m h}+\epsilon_{h}$

We do not transform the employment variables, because many houses have zero employment in some sectors. Adding an arbitrarily constant may bias the results substantially (Flowerdew and Aitkin, 1982; Burger et al., 2009). The loglinear specification imposes constant elasticities for the explanatory variables in logarithm and constant semi-elasticities for the untransformed variables, which may be as restrictive as imposing constant marginal prices.

Cheshire and Sheppard (2002), among others, apply Box-Cox transformations to the hedonic price functions in their analysis of the costs and benefits of land use planning. It allows for non-(log-)linear marginal prices of attributes and is, as we will see, a more flexible way to estimate the marginal WTP coefficients (Cheshire and Sheppard, 1998). According to Cropper et al. (1988), Box-Cox estimates produce the lowest mean percentage errors compared with loglinear and linear specifications. We specify the Box-Cox hedonic price function as follows:

$\frac{P_{h}^{\varphi}-1}{\varphi}=\alpha_{0}+\alpha_{1} D_{h}+\alpha_{2} H_{h}+\sum_{\forall g} \alpha_{g} E_{g h}+\sum_{\forall k} \beta_{k} \frac{X_{k h}^{\gamma}-1}{\gamma}+\sum_{\forall d} \beta_{d} X_{d h}+\sum_{\forall m} \beta_{m} \theta_{m h}+\epsilon_{h}$ 
where $\varphi$ and $\gamma$ are parameters to be estimated. When $\varphi$ and $\gamma$ are not significantly different from one, a linear specification is appropriate. When $\varphi$ and $\gamma$ do not deviate significantly from zero, a loglinear specification is suitable. ${ }^{6}$ Again, this functional form imposes restrictions on the willingness to pay. It now depends on one more parameters than in the linear and loglinear specifications formulated above, which adds some flexibility. Nevertheless, the willingness to pay for all characteristics depends only on the price of the house, and the value of the particular characteristic under consideration. This rules out differences between marginal willingness to pay for mixed land use aspects among inhabitants of apartments and single family houses, which will be shown to be substantial in our empirical work using semiparametric techniques.

\subsection{Semiparametric hedonic price functions}

Non-parametric estimation methods have the potential to describe the hedonic price function and the associated implicit prices more accurately when enough data are available (Sheppard, 1999). Although these methods are not yet much applied in applied urban economics, some recent empirical studies indeed estimate nonparametric and semiparametric hedonic price functions (see Bajari and Benkard, 2005; Bajari and Kahn, 2005; 2008; Bin, 2005; Bontemps et al., 2008). To avoid the 'curse of multidimensionality', Robinson (1988) proposes to estimate a partial linear model, employing a twostage estimation procedure. We follow Robinson and assume the following hedonic price function:

$P_{h}=\psi\left(D_{h}, H_{h}, E_{g h}\right)+\sum_{\forall k} \beta_{k} X_{k h}+\sum_{\forall d} \beta_{d} X_{d h}+\sum_{\forall m} \beta_{m} \theta_{m h}+\epsilon_{h}$

where $\psi(\cdot)$ is some function of mixed land use attributes. We use local linear methods to estimate $\psi(\cdot) .{ }^{7}$ That is, for each observation $h$ we run a locally weighted regression. Intuitively, local

\footnotetext{
${ }^{6}$ For the Box-Cox specification, the WTP is computed as: $\partial P_{h} / \partial E_{g h}=P_{h}^{1-\varphi} \alpha_{g}$.

7 Local methods have a lower asymptotic bias than the Nadaraya-Watson estimator and a lower asymptotic variance than the Gasser-Müller estimator, but more importantly, have been shown to generate plausible estimates of WTP coefficients (Bajari and Kahn, 2005; 2008). Robinson (1988) furthermore demonstrates that the coefficients $\beta$ can be estimated at parametric rates of convergence, despite the presence of a nonparametric part, so they are (surprisingly) efficient. A consistent estimator of the $\beta$ 's is obtained by first regressing $P_{h}, X_{k h}, X_{d h}$ and $\theta_{m h}$ on $D_{h}, H_{h}, E_{g h}$ non-parametrically. This will allow us to calculate the residuals $\varrho_{P_{h}}=P_{h}-\widehat{P}_{h}\left(D_{h}, H_{h}, E_{g h}\right), \varrho_{X_{k h}}=X_{k h}-\widehat{X}_{k h}\left(D_{h}, H_{h}, E_{g h}\right) \forall k, \quad \varrho_{X_{d h}}=X_{d h}-\widehat{X}_{d h}\left(D_{h}, H_{h}, E_{g h}\right) \forall d$ and $\varrho_{\theta_{m h}}=\theta_{m h}-$
} 
linear regressions assign greater importance to observations with attributes that are similar to $h$. The weights are computed on the basis of a kernel which is a product of standard normal distributions based on differences between attributes that are nonlinearly related to the rent. An important parameter of the kernel is the bandwidth. After visual inspection of the results, we choose a bandwidth of 3 , the same value as was previously used by Bajari and Kahn. ${ }^{8}$ We then assume that the hedonic price function locally satisfies:

$P_{h}=\alpha_{0 h}+\alpha_{1 h} D_{h}+\alpha_{2 h} H_{h}+\sum_{\forall g} \alpha_{g h} E_{g h}+\sum_{\forall k} \beta_{k} X_{k h}+\sum_{\forall d} \beta_{d} X_{d h}+\sum_{\forall m} \beta_{m} \theta_{m h}+\epsilon_{h}$.

Note that the $\alpha$ 's are now property-specific (denoted by the subscript $h$ ).

\subsection{Investigating the heterogeneity in preferences for mixed land use}

Because we use semiparametric regression methods, the marginal willingness to pay for mixed land use attributes may vary over houses. Bajari and Kahn $(2005 ; 2008)$ relate the distributions of the willingness to pay for housing attributes to characteristics of individuals. We do not have information on characteristics of home owners, but we can examine the correlation of property-specific values of the marginal willingness to pay (MWTP) for housing characteristics with the house price. As it is well known that house prices are highly correlated with income, these correlations provides information about the relationship between the value attached to mixed neighbourhoods and income (see Gan and Hill, 2008). We also investigate how the MWTP varies between different housing submarkets. There is a large literature concerning the definition of housing submarkets (see e.g. Grigsby, 1963; Galster, 1996; Watkins, 2001). Watkins (2001) argues that housing submarkets are determined by structural attributes and spatial factors. We define housing markets on the basis of price and house type. House price and type are structural attributes, but are strongly correlated with spatial factors: relatively inexpensive apartments are mainly located in highly urbanised areas, whereas more

$\hat{\theta}_{m h}\left(D_{h}, H_{h}, E_{g h}\right) \forall m$. We then regress $\varrho_{P_{h}}$ on $\varrho_{X_{k h}} \varrho_{X_{d h}}$ and $\varrho_{\theta_{m h}}$ to obtain a $\sqrt{N}$-consistent estimator of the $\beta^{\prime}$ s. The next step in the procedure is to estimate the non-linear part of the hedonic price function, denoted by $\psi(\cdot)$. We regress the residual $W_{h t}=P_{h}-\sum_{\forall k} \widehat{\beta}_{k} X_{k h}+\sum_{\forall d} \widehat{\beta}_{d} X_{d h}+\sum_{\forall m} \widehat{\beta}_{m} \theta_{m h}$ on $D_{h}, H_{h}, E_{g h}$ non-parametrically, employing local linear methods.

${ }^{8}$ In the sensitivity analysis we will provide a robustness check for the choice of bandwidth. 
expensive detached houses are often built near the urban fringe.. We may expect that households living in apartments have other preferences for mixed land use attributes than households living in detached houses. For example, households living in apartments are probably attach value to diverse urban neighbourhoods and prefer to visit local shops, whereas suburbanites, living in (semi)detached houses, have a stronger preference for low densities.

To examine the differences in preferences we regress the MWTP that follow from the local linear regressions on different house price segments:

$\hat{\alpha}_{g h}=\sum_{\forall i} \omega_{i} I_{i}+\eta_{g h}$

where $\hat{\alpha}_{g h}$ are the estimated property-specific coefficients, $\omega$ are the parameters to be estimated for each price interval $i, I$ are dummy indicators, and $\eta_{g h}$ denotes the error term. We also regress the WTP on house type. However, because house type is highly correlated with the house price, we correct for price and we report the WTP for different aspects of mixed land use for each house type, given the price: ${ }^{9}$

$\hat{\alpha}_{g h}=v_{0}+v_{1}$ terraced $_{h}+v_{2}$ semi-detached $_{h}+v_{3}$ detached $_{h}+v_{4} P_{h}+\xi_{g h}$,

where $v$ are the coefficients to be estimated and $\xi_{g h}$ denotes the error term.

\section{Results}

\subsection{Empirical Results}

In Appendix B, we present the estimates of all specifications. The structural variables have, in general, plausible signs. When a house is larger in terms of lot size or volume, the price is higher. Furthermore, more privacy (detached vs. apartment), a garage, a garden and a central heating also contribute to higher house prices. An increase in distance to the city centre leads to a decrease in the house price, ceteris paribus. Living near a railway station or highway ramp leads in general not to statistically significant changes in house prices. One percent increase in the share of ethnic minorities will lead to a decrease in residential property values with about $€ 900$ or 0.6 percent. This result is in

\footnotetext{
${ }^{9}$ For example, holding everything else constant, apartments are much cheaper than detached houses.
} 
accordance with Waddell et al. (1993), who found lower house prices when the share of Hispanics and blacks in neighbourhoods was higher. We note that the coefficients of the control variables in Model (4) are very similar to the coefficients of Model (1), which increases our confidence in the estimation procedure. 10

The coefficients of the mixed land use variables, except for Model (1), do not reveal much information about the willingness to pay for different aspects of mixed land use. We therefore compute for each model the average WTP, which is presented in Table 1. As already noted, in Model (4) the coefficients are household/property-specific.

Table 1: Average MWTP for different aspects of Mixed Land Use

\begin{tabular}{lrrrr}
\hline & $\begin{array}{c}\text { MODEL (1) } \\
\text { OLS }\end{array}$ & $\begin{array}{c}\text { MODEL (2) } \\
\text { OLS }\end{array}$ & $\begin{array}{c}\text { MODEL (3) } \\
\text { BOXCOX }\end{array}$ & \multicolumn{1}{c}{$\begin{array}{c}\text { MODEL (4) } \\
\text { SPEG }\end{array}$} \\
\hline Diversity & $€ 5,029.30$ & $€ 7,062.96$ & $€ 6,694.16$ & $€ 2,189.25$ \\
Households & $-€ 9.04$ & $-€ 7.27$ & $-€ 7.33$ & $-€ 11.40$ \\
Business Services & $€ 1.65$ & $€ 1.26$ & $€ 1.67$ & $€ 6.04$ \\
Education \& Healthcare & $-€ 0.91$ & $-€ 0.07$ & $€ 0.16$ & $€ 2.29$ \\
Government & $-€ 9.01$ & $-€ 6.12$ & $-€ 4.86$ & $-€ 15.68$ \\
Manufacturing & $-€ 13.55$ & $-€ 13.30$ & $-€ 13.94$ & $-€ 17.55$ \\
Leisure & $€ 23.81$ & $€ 6.16$ & $€ 3.96$ & $€ 37.08$ \\
Retail & $-€ 0.48$ & $-€ 1.45$ & $-€ 1.79$ & $€ 14.18$ \\
Wholesale & $-€ 40.05$ & $-€ 41.87$ & $-€ 43.19$ & $-€ 53.82$ \\
\hline
\end{tabular}

NOTE: We present the WTP for a standard deviation increase in the Diversity Index. In Model (4) we exclude WTP estimates which are more than two standard deviations away from the mean.

Different aspects of mixed land use are significantly correlated with house prices. The Diversity Index is very significant in all models and is positively related to house prices. The estimated average WTP for a one standard deviation increase in the diversity index increases house prices with $€ 2,189$ to $€ 6,694$, or 1.4-3.9 percent of the house price. We may conclude that households attach substantial value to a diversified neighbourhood. It is striking that the semiparametric estimate is much lower (about 50 percent) than the parametric estimates, suggesting that assumptions regarding the functional form of the hedonic price function are not correct.

A number of land uses have a positive impact on house prices. In general we see that the semiparametric technique leads to somewhat higher estimates for the average WTP for different land

10 We could not test whether Model (4) significantly better describes the relationship between attributes and house prices. There are some tests for functional form (for example, the Zheng test (Zheng, 1996)), but these tests involve matrix multiplications. Because we have a substantially large dataset, computational restrictions inhibit us from computing these tests. However, when we compare the mean squared error (MSE) of Models (1) and (4), it appears that the MSE is lower in the semiparametric model. 
uses. For example, the average WTP for leisure and retail is substantially higher when semiparametric techniques are employed. Sectors compatible with residential use are business services, education and healthcare, leisure and retail. Households may prefer to live close to such employment because of less commuting costs, shorter shopping trips and more intense local 'buzz' (for example, cafés and restaurants encourage active street life (Glaeser et al., 2001)). Employment in the manufacturing, government and wholesale sector is negatively related to house prices. Negative externalities related to employment in these sectors may be visual, noise and air pollution (Burnell, 1985). Housing itself is also negatively related to house prices. Households do not prefer to live in high density neighbourhoods because higher densities are often associated with a decline in residents' utility caused by negative externalities, such as reduced privacy and higher crime rates (Glaeser et al., 2005).

To get a better idea of the magnitude of the net benefits of mixed land use, we have evaluated our price function for houses located in different types of neighbourhood. Some results are presented in Table 2 . As a benchmark we use a house located in a purely residential area without any employment within 500 metres. An otherwise comparable house located near a port area is about 2.6 percent less expensive, because of negative externalities of manufacturing use. ${ }^{11} \mathrm{~A}$ house located in the city centre of Spijkenisse, with a relatively large diversity of employment, is 5.9 percent more expensive. Eventually, we evaluate a house on the Wilhelmina pier, a pronounced mixed area. Households are then willing to pay about 5.7 percent more, compared to an otherwise comparable house located in a monofunctional area. Thus, it is very important how land is mixed: a mixture including much manufacturing will generally decrease house prices, whereas a well defined mix with business and retail will lead to higher property values.

11 The columns in Table 3 represent the values of the attributes of mixed land use. For example, the house located in the port area has a diversity index of 2.67, has 291 employees in the business services sector within 500 meter etc. We estimate the percentage effect for the average house price, which is $€ 216,947$. 


\begin{tabular}{|c|c|c|c|c|c|c|c|c|c|c|}
\hline & $\begin{array}{l}\stackrel{\vec{D}}{\bar{n}} \\
\frac{0}{0} \\
\stackrel{2}{0}\end{array}$ & 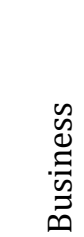 & 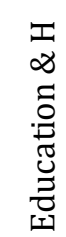 & 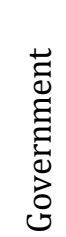 & 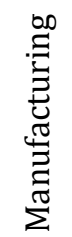 & 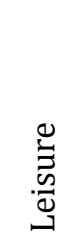 & 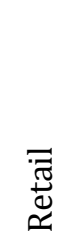 & $\begin{array}{l}\frac{0}{\pi} \\
\frac{\hat{d}}{0} \\
\frac{1}{3}\end{array}$ & 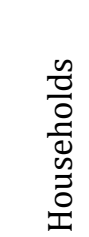 & 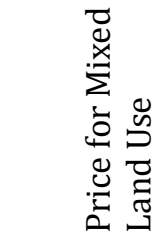 \\
\hline House located in purely residential area & 1 & 0 & 0 & 0 & 0 & 0 & 0 & 0 & 1505 & $€ 0.00$ \\
\hline House located near port area & 2.67 & 291 & 19 & 1 & 708 & 24 & 156 & 30 & 1417 & $-€ 5,624.47$ \\
\hline House located in city centre & 3.74 & 350 & 463 & 0 & 519 & 272 & 897 & 6 & 1969 & $€ 12,774.34$ \\
\hline House located in mixed area (Wilhelmina Pier) & 4.21 & 1750 & 34 & 408 & 888 & 408 & 15 & 5 & 1381 & $€ 12,396.24$ \\
\hline
\end{tabular}

\subsection{Heterogeneity in WTP for mixed land use}

We present correlations between WTP-coefficients of house price and type in Table 3. Table 4 quantifies these differences by means of a regression for different price segments. Table 5 presents the results for differences in WTP for different house types. We display histograms of the MWTPdistributions in Appendix B. These distributions do not always follow (or closely approximate) conventional normal or lognormal distributions. Because of the use of semiparametric techniques, we are able to show that households strongly differ in their MWTP for different land uses. Two observations about the results are pertinent.

Table 3: Correlations

\begin{tabular}{lcccc}
\hline & Price & Apartment & Terraced & Semi-Detached \\
\hline Diversity & -0.1960 & 0.2215 & -0.1025 & -0.1132 \\
Households & -0.3070 & 0.4459 & -0.2272 & -0.2236 \\
Business Services & 0.2956 & -0.4459 & 0.2136 & 0.2249 \\
Education \& Healthcare & 0.3076 & -0.4827 & 0.2443 & 0.2439 \\
Government & -0.1713 & 0.3760 & -0.2057 & -0.1876 \\
Manufacturing & -0.0762 & 0.2326 & -0.1294 & -0.1161 \\
Leisure & 0.3308 & -0.4351 & 0.2039 & 0.2247 \\
Retail & 0.1643 & -0.3723 & 0.2049 & 0.1817 \\
Wholesale & -0.0843 & 0.2085 & -0.1190 & -0.1048 \\
\hline
\end{tabular}

NOTE: All correlations are significant at a 0.0001 level.

Table 4: Average WTP for different price groups

\begin{tabular}{|c|c|c|c|c|c|c|}
\hline House Price $\cdot 1000$ & $€ 0-€ 100$ & $€ 100-€ 200$ & $€ 200-€ 300$ & $€ 300-€ 400$ & $€ 400-€ 500$ & $>€ 500$ \\
\hline Diversity & $€ 2,747.80$ & $€ 2,383.80$ & $€ 2,006.05$ & $€ 1,979.74$ & $€ 1,713.41$ & $€ 1,852.02$ \\
\hline Households & $-€ 10.81$ & $-€ 11.22$ & $-€ 11.63$ & $-€ 11.82$ & $-€ 11.94$ & $-€ 11.92$ \\
\hline Business Services & $€ 5.29$ & $€ 5.79$ & $€ 6.32$ & $€ 6.65$ & $€ 6.69$ & $€ 6.79$ \\
\hline Education \& Healthcare & $€ 1.08$ & $€ 1.89$ & $€ 2.80$ & $€ 3.14$ & $€ 3.36$ & $€ 3.28$ \\
\hline Government & $-€ 14.60$ & $-€ 15.19$ & $-€ 16.17$ & $-€ 16.91$ & $-€ 16.87$ & $-€ 17.03$ \\
\hline Manufacturing & $-€ 17.32$ & $-€ 17.39$ & $-€ 17.66$ & $-€ 18.04$ & $-€ 17.93$ & $-€ 17.92$ \\
\hline Leisure & $€ 32.26$ & $€ 35.81$ & $€ 38.77$ & $€ 39.91$ & $€ 41.21$ & $€ 40.94$ \\
\hline Retail & $€ 13.33$ & $€ 13.72$ & $€ 14.68$ & $€ 15.11$ & $€ 15.27$ & $€ 15.25$ \\
\hline Wholesale & $-€ 53.31$ & $-€ 53.49$ & $-€ 54.18$ & $-€ 54.64$ & $-€ 53.94$ & $-€ 54.56$ \\
\hline
\end{tabular}


Table 5: Average WTP for different house types given the house price

\begin{tabular}{lrrrr}
\hline & Apartment & Terraced & Semi-Detached & Detached \\
\hline Diversity & $€ 2,592.39$ & $€ 2,261.36$ & $€ 2,592.39$ & $€ 2,122.20$ \\
Households & $-€ 10.91$ & $-€ 11.52$ & $-€ 11.61$ & $-€ 11.77$ \\
Business Services & $€ 5.38$ & $€ 6.26$ & $€ 6.43$ & $€ 6.85$ \\
Education \& Healthcare & $€ 1.30$ & $€ 2.66$ & $€ 2.88$ & $€ 3.30$ \\
Government & $-€ 14.36$ & $-€ 16.92$ & $-€ 17.35$ & $-€ 18.20$ \\
Manufacturing & $-€ 17.11$ & $-€ 18.26$ & $-€ 18.48$ & $-€ 18.97$ \\
Leisure & $€ 33.60$ & $€ 37.50$ & $€ 38.26$ & $€ 39.68$ \\
Retail & $€ 13.06$ & $€ 15.29$ & $€ 15.63$ & $€ 16.44$ \\
Wholesale & $-€ 52.96$ & $-€ 54.71$ & $-€ 54.98$ & $-€ 55.18$ \\
\hline
\end{tabular}

First, we observe that there are some considerable correlations between price and the MWTP for different aspects of mixed land use. We quantify these differences in Table 4. Households living in expensive houses are willing to pay much less for a diversified neighbourhood than households living in less expensive houses. For example, households living in expensive houses ( $€ 400,000-€ 500,000$ ) are willing to pay $€ 1,034$ less for a standard deviation increase in diversity than households living in inexpensive houses. Households living in more expensive houses are generally willing to pay more for uses which are compatible with residential use and less for uses which are negatively related to house prices.

The second observation is that there are substantial differences in the WTP between different submarkets. Table 5 displays the correlations between house type and the diversity index and land uses. Especially for apartments, there are some strong correlations. In Table 6 we quantify these differences, conditional on the house price. It appears that households living in apartments are willing to pay $€ 353$ more for a standard deviation increase in diversity than households living in detached housing. It also appears that apartment occupiers are willing to pay $€ 0.85$ more for an additional household than households living in detached housing, although the WTP for households is still negative. Households living in apartments are willing to pay less for additional employment in the leisure and retail sector. An explanation may be that households living in apartments generally have fewer children than households living in other house types. Therefore, there is less need for leisure and retail activities in close vicinity. 


\section{Sensitivity Analysis}

In this section we will show that our results are robust to the choice of buffer size, exclusion of fixed effects, the choice of bandwidth and the formulation of the diversity index. The main results of the sensitivity analysis are presented in Table 6.

Table 6: Mean MWTP for different aspects of Mixed Land Use

\begin{tabular}{|c|c|c|c|c|c|c|c|c|}
\hline & $\begin{array}{l}\text { Buffer } \\
400 \mathrm{~m}\end{array}$ & $\begin{array}{c}\text { Buffer } \\
600 \mathrm{~m}\end{array}$ & $\begin{array}{l}\text { No Fixed } \\
\text { Effects }\end{array}$ & $\begin{array}{c}\text { Bandw } \\
2\end{array}$ & $\begin{array}{c}\text { Bandw } \\
4\end{array}$ & $M I$ & $L U I$ & $J$ \\
\hline Diversity, $D_{h}$ & $€ 2,924.06$ & $€ 3,824.53$ & $€ 4,306.75$ & $€ 3,636.07$ & $€ 1,918.84$ & & & \\
\hline Mixed Index, $M I_{h}$ & & & & & & $€ 7,272.25$ & & \\
\hline Land Use Index, $L U I_{h}$ & & & & & & & $€ 1,628.62$ & \\
\hline Job-Household Ratio, $J_{h}$ & & & & & & & & $€ 10,395.48$ \\
\hline Households & $-€ 15.51$ & $-€ 8.57$ & $-€ 10.57$ & $-€ 11.38$ & $-€ 11.37$ & $-€ 9.28$ & $-€ 11.65$ & $-€ 9.05$ \\
\hline Business Services & $€ 8.76$ & $€ 3.63$ & $€ 6.65$ & $€ 6.46$ & $€ 4.92$ & $€ 1.90$ & $€ 6.51$ & $€ 0.36$ \\
\hline Education \& Healthcare & $€ 1.29$ & $€ 1.84$ & $€ 1.52$ & $€ 2.55$ & $€ 1.84$ & $-€ 2.81$ & $€ 2.69$ & $-€ 1.39$ \\
\hline Government & $-€ 27.01$ & $-€ 7.27$ & $-€ 19.65$ & $-€ 26.64$ & $-€ 11.69$ & $-€ 17.30$ & $-€ 14.44$ & $-€ 17.04$ \\
\hline Manufacturing & $-€ 24.63$ & $-€ 15.10$ & $-€ 17.25$ & $-€ 20.99$ & $-€ 15.57$ & $-€ 22.48$ & $-€ 16.39$ & $-€ 21.72$ \\
\hline Leisure & $€ 28.68$ & $€ 30.96$ & $€ 46.76$ & $€ 51.25$ & $€ 35.25$ & $€ 40.30$ & $€ 38.35$ & $€ 41.08$ \\
\hline Retail & $€ 16.38$ & $€ 12.27$ & $€ 9.52$ & $€ 16.47$ & $€ 12.48$ & $€ 7.60$ & $€ 13.69$ & $€ 10.38$ \\
\hline Wholesale & $-€ 81.93$ & $-€ 52.57$ & $-€ 64.64$ & $-€ 63.08$ & $-€ 48.70$ & $-€ 65.05$ & $-€ 55.05$ & $-€ 59.65$ \\
\hline
\end{tabular}

First, we assumed a buffer size of $500 \mathrm{~m}$, because we can expect that the effects of mixed land use on house prices are mainly localised. We also employed buffer sizes of 400 and 600 meter to check whether our results are robust to buffer size. It appears that the results are very similar for both buffers. Generally, the WTP estimates are somewhat larger for a buffer of 400 meter and somewhat lower for a buffer of 600 meter. This may be caused by the fact that there is distance decay: the WTP for an additional employee very close to the house is larger than an additional employee further away.

Second, we have examined whether excluding municipality fixed effects generate other results. The effect of diversity is then about two times higher. The estimates of the average WTP for an additional employee in different sectors are very similar. So, it appears that only diversity is correlated with unobserved spatial factors.

Third, Bajari and Kahn (2005) and others argue that the choice of bandwidth of the kernel is important as it determines the smoothness of the function to be estimated. Our reference bandwidth is 3. We also employed bandwidths of 2 and 4 . In Table 6 we observe that the signs of the coefficients 
remain the same in all cases. It is observed that a bandwidth of 4 lead to very similar results. However, a bandwidth of 2 leads to somewhat more extreme estimates, which is reflected in a substantial higher standard deviation of the WTP-coefficients. Because the bandwidth of 2 leads to undersmoothing, we prefer our estimates with a bandwidth of 3.12

Fourth, in our study we find that households value diversity of land uses in their neighbourhood. One could argue that this result is heavily influenced by the way a land mix index is defined. We will therefore compare our diversity index $D_{h}$ with three other indices: two land use mixed indices $M I_{h}$ and $L U I_{h}$, and a job-to-households ratio $J_{h}$. The first alternative to the Diversity Index is the mixed index as defined by Pols et al. (2009) and Ritsema van Eck et al. (2009). This index is defined as follows:

$M I_{h}=\frac{\sum_{\forall g} E_{g h}}{H_{h}+\sum_{\forall g} E_{g h}}$.

When $M I_{h}=0.5$, the balance between living and working is perfect. Song and Knaap (2004) define an entropy index to measure the diversity of land uses. They define the index as follows:

$L U I_{h}=\frac{-\left(\sum_{\forall g} P_{g h} \log \left(P_{g h}\right)+P_{H h} \log \left(P_{H h}\right)\right)}{\log (G+1)}$,

where $G$ denotes the number of sectors. We add one to $G$ because we also include residential use. Higher values of $L U I_{h}$ indicate a more evenly distributed sectoral composition. The jobs-tohouseholds ratio $J_{h}$ is often used in the literature (see Margolis, 1973; Cervero, 1989; Peng, 1997). For each relevant neighbourhood measured in buffers around each house, we compute the ratio of jobs-to-households:

$J_{h}=\frac{\sum_{\forall g} E_{g h}}{H_{h}}$,

This index equals one when the balance between employment and households is perfect. We have reestimated specification (6) for these three indices. We compute for each index the MWTP for one standard deviation increase in the index. It appears that all indices are positively related to house prices. The WTP for a standard deviation increase in LUI is very comparable to the WTP for a

12 A number of weight matrices used in the kernel were nearly singular when a bandwidth of two was employed, which in turn lead to unreliable estimates. 
standard deviation increase in the diversity index. The estimates for $M I$ and $J$ are somewhat higher and comparable to parametric estimates, presented in Table 1 . We think $J$ does not a good job in describing the mixture of jobs and residents because of extreme values when the number employees in vicinity of a house is high relative to the number of households. So, the WTP for diversity a standard deviation increase in diversity ranges from about $€ 2,000$ to $€ 7,250$. So, our initial estimates may be somewhat conservative.

\section{Conclusions}

In current planning practice, more emphasis is put on mixed land use. In Europe, mixed land use has become the backbone of often implemented Compact City Concept. However, the pronounced (net) benefits or costs of mixed land use are poorly understood. In this paper we have examined whether households value mixing of employment and living, employing a semiparametric hedonic price methodology.

We first investigated the effects of a diversified environment and compute the implied WTP for different land uses not only for residents occupying single-family homes, but we also incorporate apartment occupiers. It appears that a more diversified environment is positively correlated with house prices. A one standard deviation increase in diversity leads to an increase in house prices of 1.00-4.25 percent. Households put value on diversity, but dislike high household densities. Some land uses are incompatible with residential use, such as manufacturing and wholesale. Business services, education and healthcare, leisure and retail activities are valued positively by households, although the WTP for an additional employee is in some cases very small. In general, we may conclude that a good mixture of land uses, such as businesses and leisure activities, may lead to an increase in housing values up to 6 percent, compared to a house located in a monofunctional area. It is important to note that household densities should not be too high.

Second, we showed that there is substantial heterogeneity in the WTP for different aspects of mixed land-use. For example, it appears that apartment occupiers are willing to pay more for a 
diversified neighbourhood, but less for additional employment in specific sectors. Households living in more expensive houses are willing to pay less for diversity and more for shops and leisure activities in vicinity.

There is plenty of scope for further research in this topic. First, we only take into account home owners to validate the impact and effectiveness of mixed land use. Further research could also take the preferences of the other actors into account, and examine, for example, whether mixed land use will lead to increased profits for firms. Second, we did not have information on characteristics of households. Further research could also link the preferences of households to characteristics of households, following Bajari and Benkard (2005) and Bajari and Kahn (2005). Third, we employed hedonic price techniques to measure whether house owners value different aspects of mixed land use. To measure whether mixed land use contributes to sustainability and viability of urban neighbourhoods, other methods have to be employed.

\section{References}

Anas, A., Arnott, R., Small, K. (1998). Urban Spatial Structure. Journal of Economic Literature 36: 14261464.

Aurand, A. (2010). Density, Housing Types and Mixed Land Use: Smart Tools for Affordable Housing? Urban Studies 47(5): 1015-1036.

Bajari, P., Benkard, C.M. (2005). Demand Estimation with Heterogeneous consumers and Unobserved Product Characteristics: A Hedonic Approach. Journal of Political Economy 113(6): 1239-1276.

Bajari, P. and Kahn, M.E., (2005). Estimating Housing Demand with an Application to Explaining Racial Segregation in Cities. Journal of Business \& Economic Statistics 23(1): 20-35.

Bajari, P. and Kahn, M.E., (2008). Estimating Hedonic Models of Consumer Demand with an Application to Urban Sprawl. In: A Baranzini et al. (eds). Hedonic Methods in Housing Markets.

Batty, M., Longley, P. (1994). Fractal Cities: A Geometry of Form and Function. London: Academic Press. 
Bin, 0. (2005). A Semiparametric Hedonic Model for Valuing Wetlands. Applied Economics Letters 12(10): 597-601.

Bontemps, C., Simoni, M. and Surry, Y. (2008). Semiparametric Hedonic Price Models: Assessing the Effects of Agricultural Nonpoint Source Pollution. Journal of Applied Econometrics 23: 825-842.

Burnell, J.D. (1985). Industrial Land Use, Externalities, and Residential Location. Urban Studies, 22(5): 399-408.

Breheny, M. (1992). Sustainable Development and Urban Form. London: Pion.

Breheny, M. (1995). The Compact City and Transport Energy Consumption. Transactions of British Geographers 20: 81-101.

Burger, M.J., Van Oort, F. and Linders, G.J. (2009). On the Specification of the Gravity Model of Trade: Zeros, Excess Zeros and Zero-inflated Estimation. Spatial Economics Analysis 4(2): 167-190.

Calthorpe, P. and Fulton, W. (2001). The Regional City. Island Press, Washington DC.

Cao, T.V. and Cory, D. (1981). Mixed Land uses, Land-use Externalities, and Residential Property Values: a Re-evaluation. Annals of Regional Science 16, 1-24.

Cervero, R. (1989). Jobs-housing Balance and Regional Mobility. Journal of the American Planning Association 55(2): 136-151.

Cheshire, P. and Sheppard, S. (1998). Estimating the Demand for Housing, Land and Neighbourhood Characteristics. Oxford Bulletin of Economics and Statistics 60(3): 357-382.

Cheshire, P. and Sheppard, S. (2002). The Welfare Economics of Land-use Planning. Journal of Urban Economics 52: 242-269.

Coupland, A. (ed.) (1997). Reclaiming the City: Mixed-use Development. E \& FN SPON (1997), London. Cropper, M.L., Deck, L.B. and McConnell, K.E. (1988). On the Choice of Functional Form for Hedonic Price Functions. The Review of Economics and Statistics 70(4):668-675.

Dieleman, F.M., Dijst, M.J., Spit, T. (1999). Planning the Compact City: the Randstad Holland Experience. European Planning Studies 7(5): 605-621. 
Duranton, G. and Puga, D. (2000). Diversity and Specialisation in Cities: Why, Where and When Does it Matter? Urban Studies 37(3): 533-555.

Ekeland, I., Heckman, J.J. and Nesheim, L. (2004). Identification and Estimation of Hedonic Models. Journal of Political Economy 112: 60-109.

Flowerdew, R. and Aitkin, M. (1982). A Method of Fitting in the Gravity Model Based on the Poisson Distribution. Journal of Regional Science 22: 191-202.

Faludi, A., Van der Valk, A.J. (1994). Rule and Order: Dutch Planning Doctrine in the Twenthieth Century. Dordrecht: Kluwer Academic.

Freeman, A.M. (1993). The Measurement of Environmental and Resource Values: Theory and Methods. Resources for the future, Washington, DC.

Galster, G. (1996). William Grigsby and the Analysis of Housing Sub-Markets and Filtering. Urban Studies 33(10): 1797-1805.

Gan, Q. and Hill, R.J. (2008). A New Perspective on the Relationship Between House Prices and Income. UNSW Australian School of Business Research Paper ECON 13.

Gibbons, S. and Machin, S. (2005). Valuing Rail Access Using Transport innovations. Journal of Urban Economics 57: 148-169.

Glaeser, E.L., Gyourko, J. and Saks, R.E. (2005). Why have housing prices gone up? American Economic Review 95(2): 329-333.

Glaeser, E.L., Kolko, J. and Saiz, A. (2001). Consumer City. Journal of Economic Geography 1:27-50

Gomez-Ibanez, J. (1991). A Global View of Automobile Dependence - review of Newmann P., Kenworthy, J.. Cities and Automobile Dependence: a Sourcebook. Journal of the American Planning Association 57: 376-379.

Grant, J. (2004). Encouraging Mixed Use in Practice. Paper presented at the International Planning Symposium on Incentives, Regulations, and Plans - The Role of States and Nation-States in Smart Growth Planning. September 1 - October 1, 2004, Maryland.

Grigsby, W. (1963). Housing Markets and Public Policy. University Of Pennsylvania Press, Philadelphia. 
Griliches, Z. (1961). Hedonic Price Indexes for Automobiles: An Econometric Analysis of Quality Change. In: The Price Statistics of the Federal Government, pp. 173-196.

Handy, S. (1992). Regional versus Local Accessibility. Built Environment 18: 301-313.

Jacobs, J. (1961). The Death and Life of Great American Cities. Random House, New York.

Kiel, K. and Zabel, J. (2001). Estimating the Economic Benefits of Cleaning-up Superfund Sites: the Case of Woburn, Massachusetts. Journal of Real Estate Finance and economics 22: 163-184.

Koomen, E., Dekkers, J. and Dijk, T. van (2008). Open-space Preservation in the Netherlands: Planning, Practice and Prospects. Land Use Policy 25: 361-377.

Korthals Altes, W.K. (2007). The Impact of Abolishing Social-Housing Grants on Compact-City Policy of Dutch Municipalities. Environment and Planning A 39: 1497-1512.

Lafferty, R.N. and Frech, H.E. (1978). Community Environment and the Market Value of Single Family Homes: the Effect of Dispersion of Land Eses. Journal of Law and Economics, Vol. 21, 381-394.

Margolis, J. (1973). Municipal Fiscal Structure in a Metropolitan Region. In: R.E. Grieson (ed). Urban Economics: Readings and Analysis. Little Brown, Boston.

Municipality of Rotterdam (2007). Stadsvisie Rotterdam: Rotterdam 2030. Gemeente Rotterdam.

Municipality of Rotterdam (2010). Collegewerkprogramma Rotterdam 2010-2014: Werken aan Talent en Ondernemen. Gemeente Rotterdam.

Palmquist, R.B. (1992). Valuing Localized Externalities. Journal of Urban Economics 31(1), pp 59-68.

Peng, Z.R. (1997). The Jobs-housing Balance and Urban Commuting. Urban Studies 34(8): 1215-1235.

Pols, L., Van Amsterdam, H., Harbers, A., Kronberger, P. and Buitelaar, E. (2009). Menging van Wonen en Werken. The Hague/Bilthoven: Planbureau voor de Leefomgeving.

Ritsema van Eck, J., Van Amsterdam, H. and Van der Schuit, J. (2009). Ruimtelijke Ontwikkelingen in een Stedelijk Gebied. Dynamiek Stedelijke Milieus 2000-2006. The Hague/Bilthoven: Planbureau voor de Leefomgeving.

Robinson, P.M. (1988). Root-N-Consistent Semi-Parametric Regression. Econometrica 57: 1403-1430. 
Rosen, S. (1974). Hedonic Prices and Implicit Markets: Product Differentiation in Pure Competition. Journal of Political Economy 82: 34-55.

Rouwendal, J. and Straaten, J.W. van der (2008). The Costs and Benefits of Providing Open Space in Cities. Tinbergen discussion paper: TI 2008-001/3

Rowley, A. (1996). Mixed-use Development: Ambiguous Concept, Simplistic Analysis and Wishful Thinking? Planning Practice and Research 11(1): 85-97.

Sheppard, S. (1999). Hedonic Analysis of Housing Markets. Handbook of Regional and Urban Economics, vol. 3, pp. 1595-1635, Elsevier.

Song, Y. and Knaap, G.J. (2003). New Urbanism and Housing Values: a Disaggregate Assessment. Journal of Urban Economics, 54: 218-238.

Song, Y. and Knaap, G.J. (2004). Measuring the Effects of Mixed Land Uses on Housing Values. Regional Science and Urban Economics 34: 663-680.

Statistics Netherlands (2007). Inwoners Randstat Verdienen het Meest. http://www.cbs.nl/.

Van der Valk, A. (2002). The Dutch Planning Experience. Landscape and Urban Planning 58: 201-210.

Vreeker, R., Groot, H.L.F., Verhoef, E.T. (2004). Urban Multifunctional Land Use: Theoretical Insights on Economies of Scale, Scope and Diversity. Built Environment 30(4): 289-307.

Waddell, P., Berry, B.J.L. and Hoch, I. (1993). Residential Property Values in a Multimodal Area: New Evidence on the Implicit Price of Location. Journal of Real Estate Finance and Economics 7: 117-141.

Watkins, C. (2001). The Definition and Identification of Housing Submarkets. Environment and Planning A 33: 2235-2253.

Working Group on Sustainable Land Use (2001). Towards More Sustainable Urban Land Use. Advice to the European Commission for Policy and Action.

Wright, A. (1967). Chang'an. In: A. Toynbee (ed). Cities of destiny, pp. 138-139. Thames and Hudson, London.

Zheng, J.X. (1996). A Consistent Test of Functional Form via Nonparametric Estimation Techniques. Journal of Econometrics 75(2): 263-289. 


\section{Appendix A. Descriptives}

Table A1: Descriptive Statistics

\begin{tabular}{|c|c|c|c|c|c|}
\hline \multicolumn{3}{|c|}{ Other } & \multicolumn{3}{|c|}{ Mixed Land Use Variables } \\
\hline Variable Name & Mean & Std.Dev. & Variable Name & Mean & Std.Dev. \\
\hline House Price & 216947.05 & $(137284.42)$ & Diversity, $D_{h}$ & 2.05 & $(0.88)$ \\
\hline Volume $\left(\mathrm{m}^{3}\right)^{*}$ & 316.43 & $(138.38)$ & Mixed Index, $M I_{h}$ & 0.30 & $(0.18)$ \\
\hline Size $\left(m^{2}\right)^{*}$ & 113.77 & $(44.97)$ & Land Use Index, $L U I_{h}$ & 0.44 & $(0.18)$ \\
\hline Terraced & 0.31 & $(0.46)$ & Job-Household Ratio, $J_{h}$ & 0.60 & $(0.81)$ \\
\hline Semi-Detached & 0.17 & $(0.37)$ & Households & 2714.00 & $(1618.14)$ \\
\hline Detached & 0.04 & $(0.19)$ & Business Services & 431.49 & (1102.79) \\
\hline Rooms & 4.05 & $(1.35)$ & Education \& Healthcare & 456.74 & $(695.77)$ \\
\hline Garage & 0.05 & $(0.21)$ & Government & 123.71 & $(369.15)$ \\
\hline Garden & 0.48 & $(0.50)$ & Manufacturing & 220.88 & (391.16) \\
\hline No Central Heating & 0.08 & $(0.27)$ & Leisure & 122.10 & $(288.37)$ \\
\hline Monument & 0.00 & $(0.06)$ & Retail & 252.87 & (382.86) \\
\hline Construction 1961-1970 & 0.14 & $(0.35)$ & Wholesale & 46.45 & (99.42) \\
\hline Construction 1971-1980 & 0.14 & $(0.34)$ & & & \\
\hline Construction 1981-1990 & 0.15 & $(0.36)$ & & & \\
\hline Construction 1991-2000 & 0.17 & $(0.37)$ & & & \\
\hline Construction $\geq 2001$ & 0.07 & $(0.25)$ & & & \\
\hline Distance Centre & 8.20 & $(6.00)$ & & & \\
\hline Distance Highway Ramp & 2.28 & (1.64) & & & \\
\hline Distance Station & 2.88 & $(2.89)$ & & & \\
\hline Distance to Open Space & 0.17 & $(0.14)$ & & & \\
\hline Share of Ethnic Minorities & 28.91 & $(17.10)$ & & & \\
\hline
\end{tabular}




\section{Appendix B. Other results}

Table B1: Results for different specifications

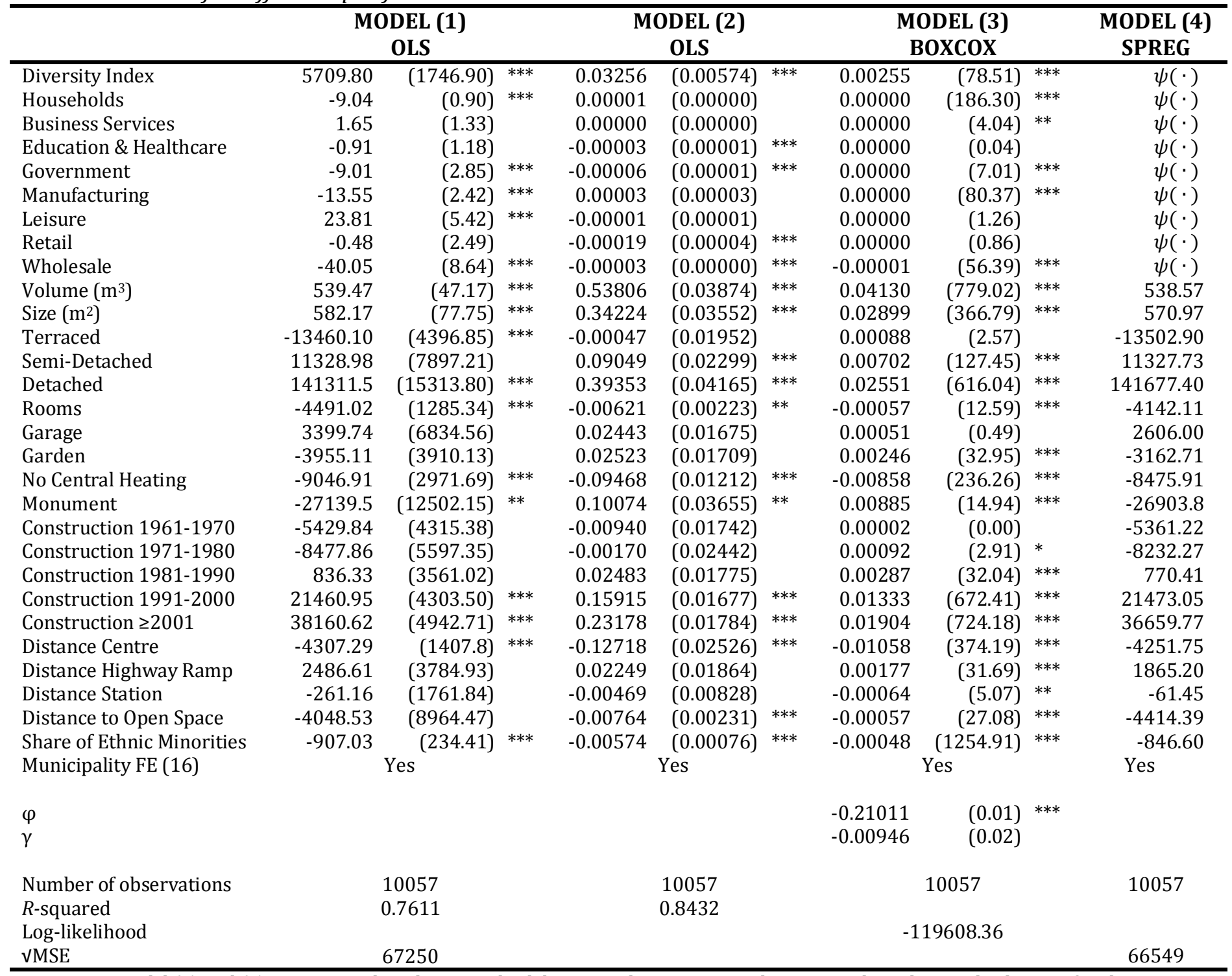

NOTE: For Model (1) and (2) we present the robust standard deviations between parentheses. We adjust the standard errors for clustering on municipality level. For Model (3) we present the chi-square values and the standard errors for the transformation coefficients between parentheses. Coefficients are significant at ${ }^{*} 0.10,{ }^{* *} 0.05$ and ${ }^{* * *} 0.01$ levels. Full results are available upon request. 


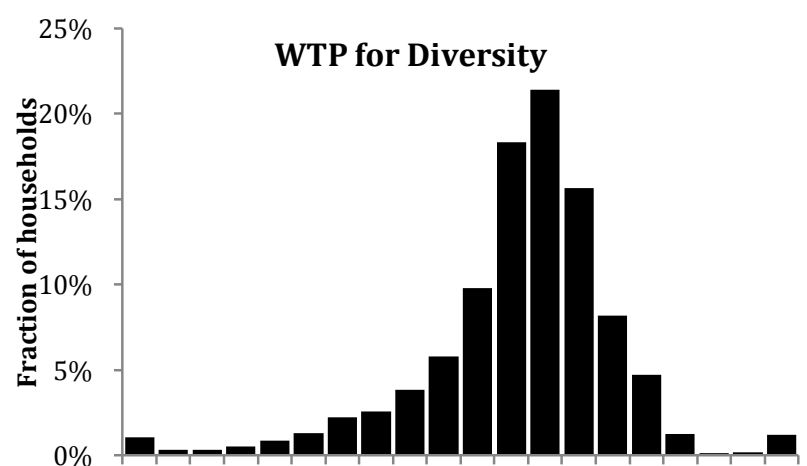

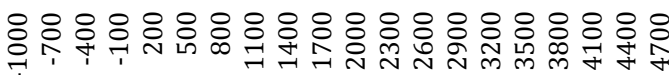

$\checkmark$ WTP for one standard deviation increase in $€$

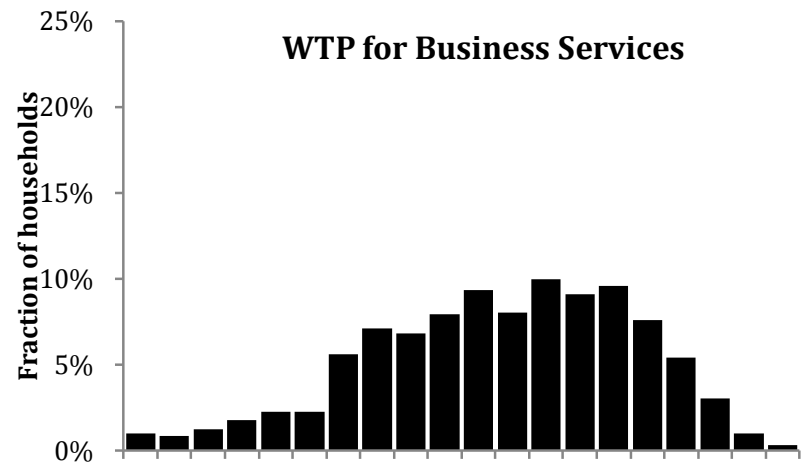

வे户்

WTP for one employee increase in $€$

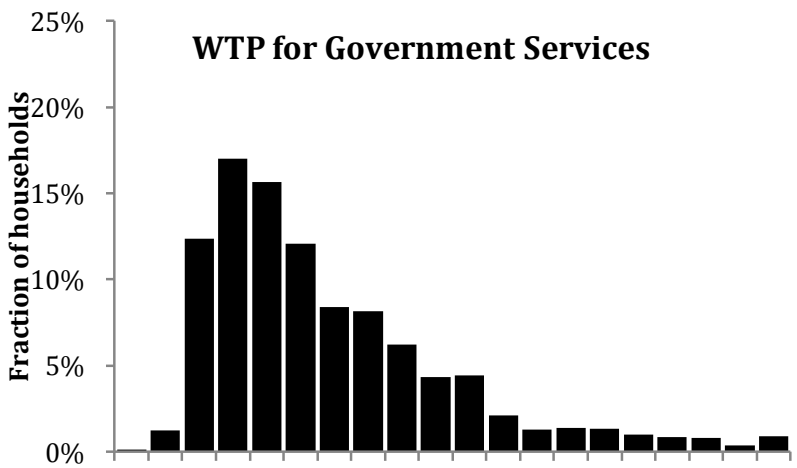

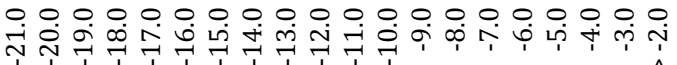
WTP for one employee increase in $€$
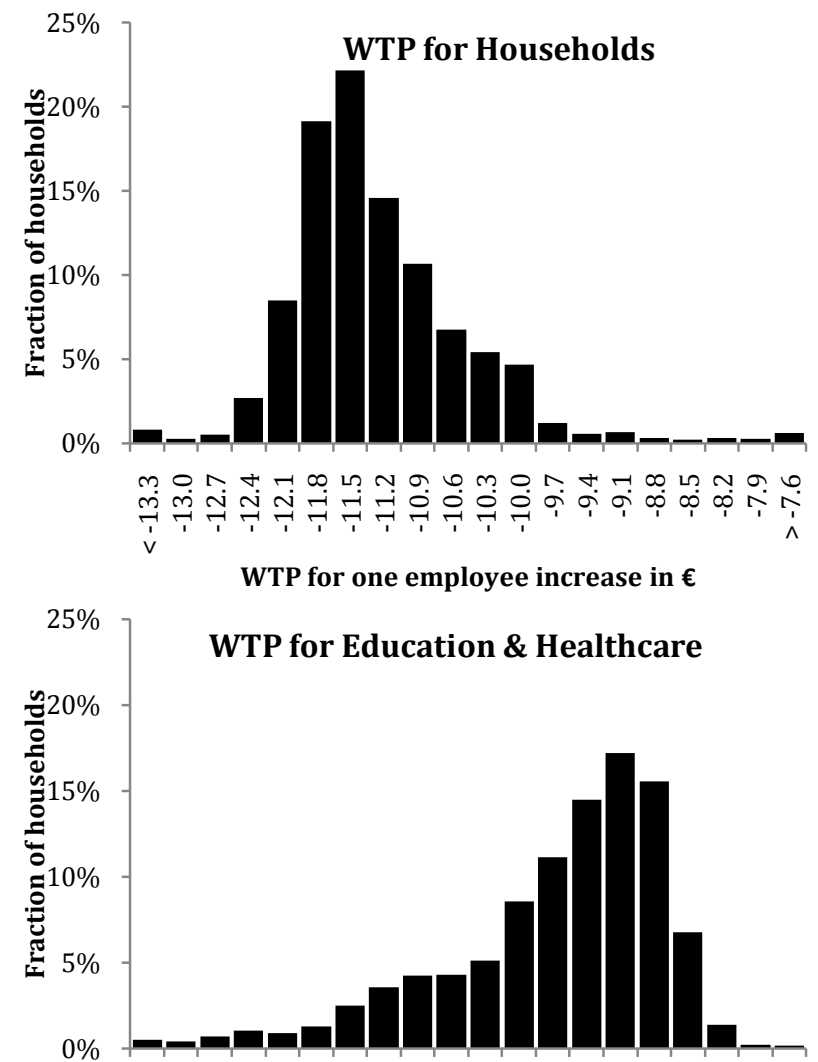

岗

WTP for one employee increase in $€$

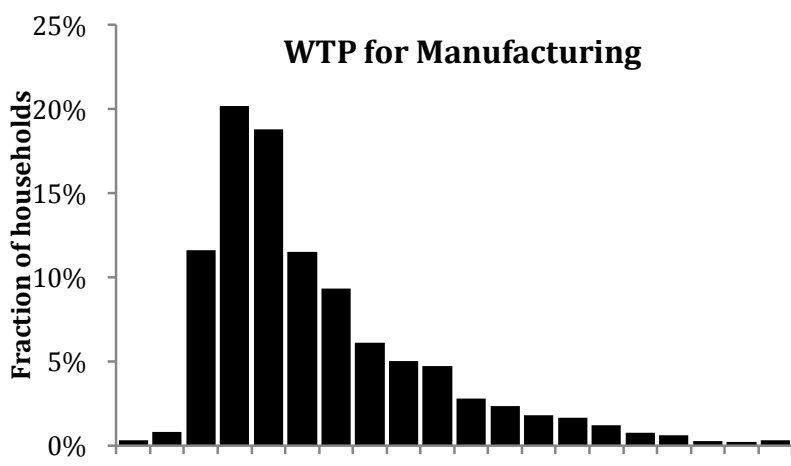

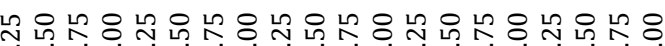

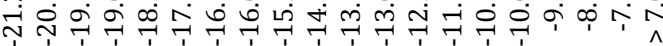
WTP for one employee increase in $€$ 


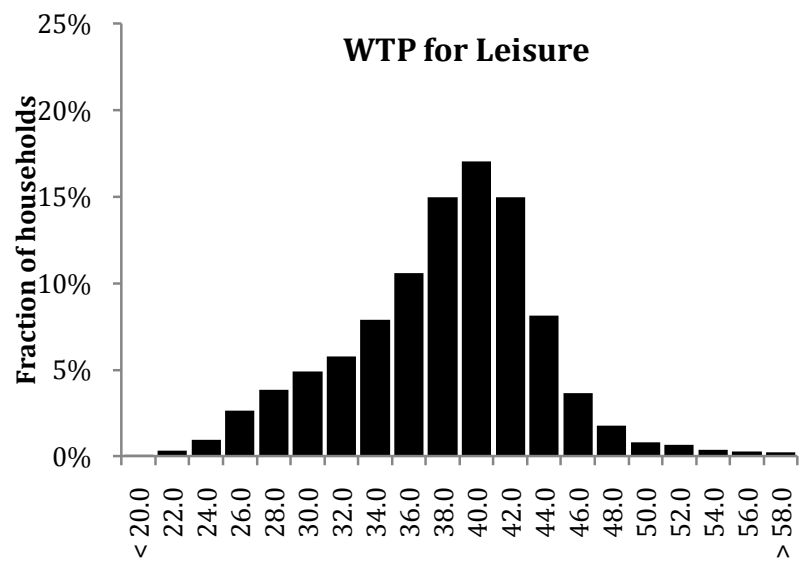

WTP for one employee increase in $€$

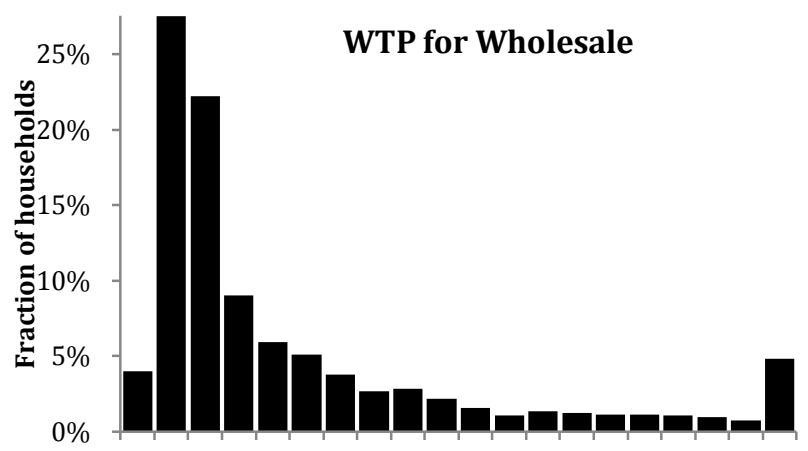

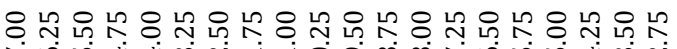

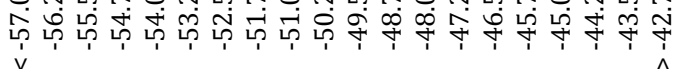
WTP for one employee increase in $€$

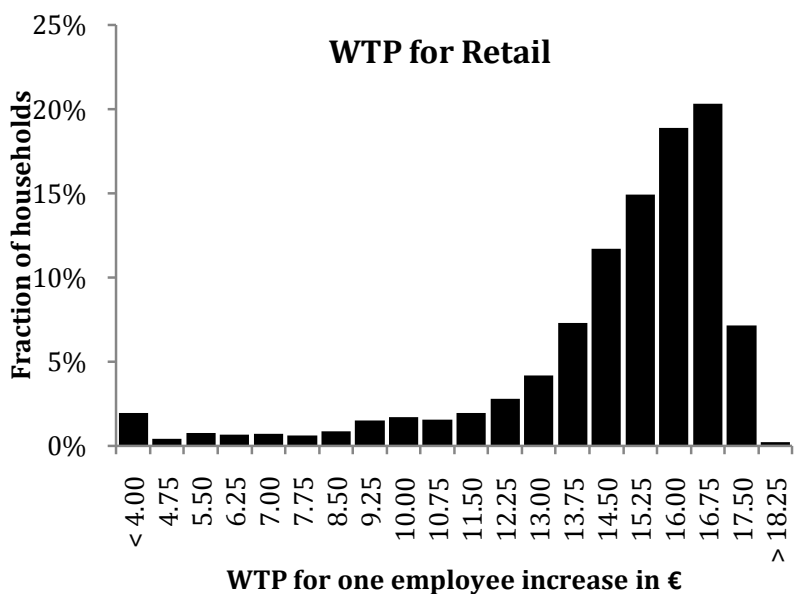

WTP for one employee increase in $€$ 